\title{
Актуальность разработки информационной системы обеспечения малой изолированной энергетики Севера
}

\author{
Спасов Р.А., Лямкин К.О., \\ Технический институт (филиал) \\ Северо-Восточного федерального университета, г. Нерюнгри \\ E-mail: spasov1997r@mail.ru
}

\section{Научный руководитель: к.т.н., доцент Киушкина В.P.}

ГИС являются серьёзным аналитическим инструментом для интеллектуального анализа данных функционирования энергетического хозяйства, что позволяет обеспечить большую эффективность исключая при этом человеческие факторы, а так же давая возможность прогнозирования, управление энергетической инфраструктурой.

Энергетическая отрасль предоставляет благоприятное поле для широкомасштабного использования уникальных возможностей геоинформационных систем. Поскольку большинство аспектов этого многогранной деятельности имеет значимую пространственную составляющую и привязку к определенной территории или конкретному местоположению. Связанные с географическим положением данные пронизывают все стадии процесса: от полевых разведочных работ, создания и развертывания инфраструктуры, добычи (генерации), хранения, транспортировки (передачи) и сбыта. Это в полной мере относится и к таким направлениям деятельности энергетических компаний как логистика, соблюдение экологических требований, вопросы обеспечения безопасности и реагирования на чрезвычайные ситуации, энергосбережения и увеличения энергоэффективности ТЭК.

ГИС в электроэнергетике давно получила статус инфраструктурной технологии и рассматривается всеми ИТ-консультантами как базовая технология для построения корпоративной ИТ-архитектуры энергетических компаний. 90\% информации, используемая на предприятиях электроэнергетики имеет пространственную привязку в силу географически распределенной природы основных активов: транспортные и распределительные электрические сети и вся сопутствующая инфраструктура.

Так как особенностями изолированной энергетики является использование, во многих случаях, не традиционной энергетики, то есть ВЭС, гелиостанциях, геотермальных ЭС и т.д., поэтому геоинформационные системы актуальны для изолированных районов. Благодаря общему банку информаций этих систем можно определить координаты, пригодный ландшафт и погодные условия для того или иного типа электростанций.

Геоинформационные системы так же способствуют ускорению перехода к распределенной генерации, главной особенностью которой является снижение потерь электрической энергии, повышение надежности и устойчивости ЭЭС. ГИС дают информацию и просчитывают наилучший вариант создание систем распределенной генерации, что, в свою очередь, повлияет на эффективность в эконмическом плане, надежности, безопасности и уменьшению негативных факторов, способных повлиять на расчеты и создание общей электроэнергетической системы. ГИС детально учитывают месторасположение и площадь объектов. Комплексный анализ, проводимый системой одновременно на основе нескольких факторов, позволяет 
получить наиболее точную и объективную оценку территории с позиции заданных параметров. Таких как скорость ветра, уровень и скорость течения рек, характеристики местности и т.д. Геоинформационные системы очень эффективны для определения места размещения объекта, они помогают урегулировать территориальные споры и способны оказать реальное содействие в координации деятельности оперативных служб во время чрезвычайных ситуаций. Запрашиваемая информация предоставляется в виде подробных карт с дополнительной детализацией в форме текстов, схем, графиков и диаграмм. Так ГИС активно используется крупными международными компаниями.

Для формирования способов создания единой информационной системы по Республики Саха на основе ГИС необходимы следующие базы данных с качеством оценки (таблица 1) и базы данных по возобновляемым источникам энергии (таблица 2).

\begin{tabular}{|c|c|}
\hline & Таблиц \\
\hline Качество оценок & Источники данных \\
\hline $\begin{array}{l}\text { Максимальная оценка } \\
\text { энергопотенциала } \\
\text { территории }\end{array}$ & $\begin{array}{l}\text {-Данные метеостанций региона (Республика Саха) } \\
\text {-Данные NASA SSE } \\
\text {-RetScreen (Программное обеспечение для оценки проектов ВИЭ) }\end{array}$ \\
\hline $\begin{array}{l}\text { Промежуточный уровень } \\
\text { оценки }\end{array}$ & $\begin{array}{l}\text {-Данные метеостанций (Россия) } \\
\text {-Данные NASA SSE }\end{array}$ \\
\hline Наиболее общая оценка & $\begin{array}{l}\text {-WRDC (Мировой центр радиационных данных) } \\
\text {-Данные NASA SSE }\end{array}$ \\
\hline
\end{tabular}

Таблица 2

\begin{tabular}{|c|c|c|c|}
\hline & $\begin{array}{c}\text { Условия } \\
\text { доступа }\end{array}$ & Web - адрес & Охват территории \\
\hline $\begin{array}{c}\text { WRDC } \\
\text { (Мировой центр } \\
\text { радиациооных данных) }\end{array}$ & Бесплатно & http://wrdc.mgo.rssi.ru & Всемирная \\
\hline $\begin{array}{c}\text { RetScreen } \\
\text { (Канада, программное } \\
\text { обеспечение для оценки } \\
\text { проектов ВИЭ }\end{array}$ & Бесплатно & $\underline{\text { http://www.nrcan.gc.ca }}$ & Всемирная \\
\hline
\end{tabular}

\section{Список литературы:}

1. Энергетика XXI века: Условия развития, технологии, прогнозы / Л.С.Беляев, А.В. Лагерев, В.В. Посекалин; Отв. ред. Н.И.Воропай. Новосибирск: Наука, 2004.

2. Геоинформационные системы / Власов М.Ю., Горбачев В.Г.; Центр системных исследований "Интегро"; Уфа: 2007.

3. Электронный ресурс: портал по тригенерации, когенерации и мини-ТЭЦ; статья Распределенная генерация в электроэнергетических системах; (http://www.combienergy.ru/stat/983-Raspredelennaya-generaciya-v-elektroenergeticheskihsistemah); д.о. [9.12.16].

4. Электронный ресурс: портал еsri cis; статья - ГИС для энергетики; (http://esricis.ru/news/arcreview); д.о. [5.12.16].

5. Электронный ресурс: портал GIS_LOUNGE; статься - GIS and Sustainable Energy; (https://www.gislounge.com/gis-sustainable-energy/); д.о. [5.12.16].

6. Электронный ресурс: портал reVOLT; статья The Role of GIS Mapping in 
Renewable Energy Project Planning; (http://blogs.worldwatch.org/revolt/the-role-of-gismapping-in-renewable-energy-project-planning/); д.о. [26.11.16].

7. Электронный ресурс: портал Data+; статья - Гис в электроэнергетике: интеллектуальные энергосистемы; (http://www.dataplus.ru/news/arcreview); д.o. [22.11.16].

\title{
Укрепление экологической безопасности возобновляемой энергетикой
}

\author{
Суфлян Д.А., студентка, \\ Технический институт (филиал) \\ Северо-Восточного федерального университета, г. Нерюнгри \\ E-mail: Suf15@mail.ru
}

Научный руководитель: к.т.н., доцент Киушкина В.Р.

В современных условиях любой объект вне зависимости от его специализации оказывает воздействие на окружающую среду. Это воздействие в каждом конкретном случае неодинаково. Прежде всего, оно зависит от применяемых технологий, квалификации и исполнительской дисциплины обслуживающего персонала предприятия, степени аварийности и прочих факторов.

В республике Саха Якутия одним из факторов загрязнения окружающей среды являются объекты, генерирующие электрическую и тепловую энергию (рис.1).

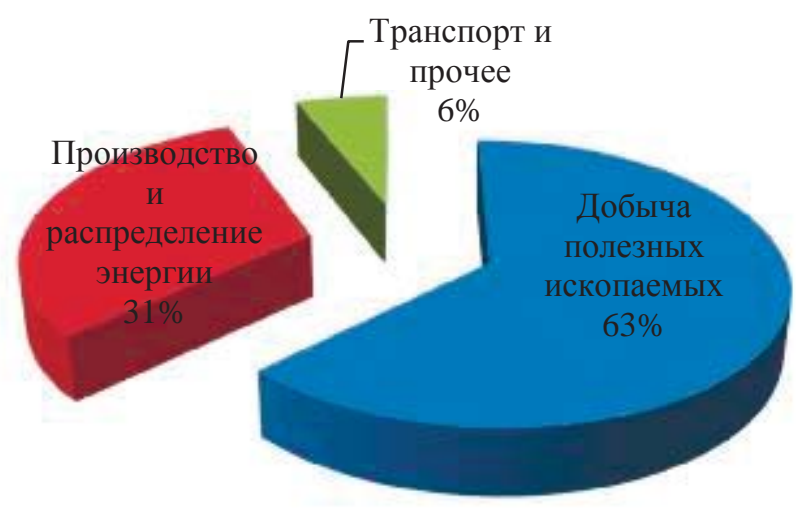

Рис. 1. Структура выбросов загрязняющих атмосфер веществ на 2015 год по республике Саха Якутия, \% [1]

Установленная мощность генерирующих источников по республике представлена в таблице 1.

Таблица 1 [2]

\begin{tabular}{|l|c|c|}
\hline \multicolumn{1}{|c|}{ Показатели } & $\begin{array}{c}\text { Единицы } \\
\text { измерения }\end{array}$ & Отчетные значения \\
\hline Всего по Республике Саха (Якутия) & млн кВт.ч & 6590,1 \\
\hline Электропотребление & млн кВт.ч & 8347,3 \\
\hline Выработка & & \\
\hline в том числе: & \\
\hline
\end{tabular}

